\title{
Thermodynamic properties of pepper seeds - variety 'Cabacinha'
}

\section{Propriedades termodinâmicas das sementes de pimenta - variedade Cabacinha}

\author{
Hellismar Wakson da SILVA ${ }^{1}$; Lílian Moreira COSTA ${ }^{2}$; Osvaldo RESENDE ${ }^{3}$; Daniel Emanuel Cabral de \\ OLIVEIRA; ; Renato Silva SOARES ${ }^{5}$; Luís Sérgio Rodrigues VALE \\ ${ }^{1}$ Autor para correspondência, Engenheiro Agrônomo, Mestrando em Agronomia/Fitotecnia, Universidade Federal de \\ Lavras - MG, Brasil, waksonhellismar@gmail.com. \\ ${ }^{2}$ Mestre em Ciências Agrárias, Instituto Federal de Educação, Ciência e Tecnologia Goiano - Câmpus Rio Verde - GO, \\ Brasil, Imctpg@yahoo.com.br. \\ ${ }^{3}$ Dr. em Engenharia Agrícola, Instituto Federal de Educação, Ciência e Tecnologia Goiano - Câmpus Rio Verde - GO, \\ Brasil, osvresende@yahoo.com.br. \\ ${ }^{4}$ Doutorando em Ciências Agrárias - Agronomia, Instituto Federal de Educação, Ciência e Tecnologia Goiano - Câmpus \\ Rio Verde - GO, Brasil, oliveira.d.e.c@gmail.com. \\ ${ }^{5}$ Engenheiro Agrônomo, Mestrando em Agronomia/Genética e Melhoramento de Plantas, Universidade Estadual \\ Paulista Júlio de Mesquita Filho - Câmpus de Jaboticabal - SP, Brasil, renato_2366@hotmail.com. ${ }^{6}$ Dr. em Agronomia, \\ Instituto Federal de Educação, Ciência e Tecnologia Goiano - Câmpus Ceres - GO, Brasil, luis.sergio@ifgoiano.edu.br.
}

Recebido em: 01-12-2014; Aceito em: 21-08-2015

\begin{abstract}
Drying is one of the most important steps of the post-harvest of pepper seeds and must be performed carefully so as not to impair the quality of seeds. The study of thermodynamic properties provides information about the behavior of water in agriculture products and the energy requirement for removal thereof during the drying process. Based on the above, this study aimed to determine and evaluate the thermodynamic properties for different equilibrium moisture contents in pepper seeds of the variety 'Cabacinha'. Seeds with an initial moisture content of $22.7 \%$ on dry basis (d.b.) were subjected to drying at $40{ }^{\circ} \mathrm{C}$, until reaching moisture content of $3.9 \%$ (d.b.). Based on the obtained results, it is concluded that the integral isosteric heat of desorption, the Gibbs free energy, the differential enthalpy and entropy increase with the reduction of the moisture content of pepper seeds. The Gibbs free energy showed positive values, indicating that the process of desorption is not spontaneous. The theory of the enthalpy-entropy compensation can be applied to the desorption process, since this is controlled by enthalpy.
\end{abstract}

Additional keywords: Capsicum chinense L.; isokinetic temperature; isosteric heat; moisture content.

\section{Resumo}

A secagem é uma das etapas mais importantes da pós-colheita de sementes de pimenta, devendo ser realizada cuidadosamente para não prejudicar a qualidade das sementes. O estudo das propriedades termodinâmicas fornece informações sobre o comportamento da água em produtos agrícolas e o requerimento de energia para a remoção da mesma durante o processo de secagem. Com base no exposto, objetivou-se, com o presente trabalho, determinar e avaliar as propriedades termodinâmicas, para diferentes teores de água de equilíbrio, em sementes de pimenta da variedade Cabacinha. As sementes, com teor de água inicial de 22,7\% (b.s.), foram submetidas à secagem, à temperatura de $40^{\circ} \mathrm{C}$, até atingir teor de água de $3,9 \%$ (b.s.). Com base nos resultados obtidos, conclui-se que o calor isostérico integral de dessorção, a energia livre de Gibbs, a entalpia e a entropia diferencial aumentam com a redução do teor de água das sementes de pimenta. A energia livre de Gibbs apresentou valores positivos, indicando que o processo de dessorção não é espontâneo. A teoria da compensação entalpia-entropia pode ser aplicada ao processo de dessorção, visto que este é controlado pela entalpia.

Palavras-chave adicionais: calor isostérico; Capsicum chinense L.; temperatura isocinética; teor de água.

\section{Introduction}

Among the production steps of pepper seeds of the genus Capsicum, reducing the moisture content, by drying, comprises one of the most important factors in preserving the germination and vigor of seeds during storage. Thus, it is necessary to have prior knowledge of the water sorption characteristics of the product, to establish, then, the most suitable conditions (drying time, initial and final moisture content, drying temperature and air velocity) for drying the seeds.

Knowledge on the hygroscopic behavior of agricultural products is a key factor in the projects and studies of drying, handling, storage, packaging and transport systems and in modeling longevity of seeds, grains and other agricultural products (Araújo et al., 2001). 
In this sense, the hygroscopic behavior of agricultural products may be analyzed by means of isothermal curves or hygroscopic equilibrium curves, which is the relation between the moisture content of a certain product and the equilibrium water activity to a specific temperature (Resende et al., 2006).

From the sorption isotherms is possible to calculate the thermodynamic properties of a product, which provide information on energy demand and prediction of kinetic parameters in sorption processes (Kaya \& Kahyaoglu, 2006). Furthermore, the thermodynamic properties that include the integral isosteric heat of sorption, the differential enthalpy and entropy of sorption and the theory of compensation can also be used to analyze and understand the state of water equilibrium with the vicinity according to the temperature and water activity (Fasina, 2006; Thys et al., 2010).

The isosteric heat of sorption is used as an indicator of the intermolecular forces of attraction between the product sorption sites and the water vapor (Al-Muhtaseb et al., 2004; Moreira et al., 2008), and, the lower the moisture content of the product, the greater will be the energy needed for its removal (Costa et al., 2013; Oliveira et al., 2011).

The changes in enthalpy values may provide a measure of changes in energy occurring by mixing water molecules with the constituents of the product during the sorption processes (Telis-Romero et al., 2005). Entropy changes may also be associated with the system binding/repulsion forces and the spatial arrangement of the product-water ratio (McMinn et al., 2005). Hence, the entropy of a material is proportional to the number of adsorption sites available at a particular level of energy (Madamba et al., 1996).

The theory of the enthalpy-entropy compensation, or isokinetic theory, is used to evaluate the physical and chemical phenomena, such as the sorption reactions. The theory proposes that the nature of the interaction between the solute and the solvent causes the sorption reaction, and that the relation between the enthalpy and entropy for a particular reaction is linear (Fasina, 2006).

The Gibbs free energy evaluates the affinity between the product and the water, which may indicate whether the product water output, during the drying process, is spontaneous or not. If the value of this property is positive, the process is not spontaneous; if negative, the process occurs spontaneously (Telis et al., 2000).

Given that the thermodynamic properties of agricultural products provide important information about the behavior of water and the energy need for its removal in organic products, it becomes imperative to know the behavior of the thermodynamic properties of pepper seeds, once in literature there is limitation of information for this type of product.

Based on the above, the aim of this study was to determine and evaluate the thermodynamic properties depending on different moisture contents of pepper seeds of the variety 'Cabacinha'.

\section{Material and methods}

The experiment was conducted at the Laboratory of Post-harvest of Plant Products of the Federal Institute of Education, Science and Technology of Goiás - Rio Verde Campus (IF Goiano - Rio Verde Campus), located in the city of Rio Verde, GO.

It was used a batch of pepper seeds of the variety 'Cabacinha' (Capsicum chinense L.) produced at the Federal Institute of Goiás - Ceres Campus, GO. After mechanical extraction, it was carried out predrying of the seeds in natural laboratory conditions at $24.6 \pm 1.2^{\circ} \mathrm{C}$ and $73.1 \pm 6.5 \%$ relative air humidity for 24 hours. Then the seeds were sent to the Laboratory of Post-harvest of Plant Products of the Federal Institute of Education, Science and Technology of Goiás - Rio Verde Campus (IF Goiano - Rio Verde Campus), where the experiment was conducted.

In order to obtain different moisture contents, the seeds were dried in an oven with forced ventilation at $40^{\circ} \mathrm{C}$, until reaching the moisture contents of 22.7 ; $17.8 ; 14.8 ; 11.4 ; 8.5 ; 5.6$ and $3.9 \%$ on dry basis (d. b.).

The moisture contents were determined by the method of oven at $105 \pm 3^{\circ} \mathrm{C}$, for 24 hours, in two replications (Brasil, 2009), and converted to percentage on dry basis (\% d. b.).

For the determination of the isotherms of desorption of seeds, it was used the indirect static method, being the water activity $\left(a_{w}\right)$ determined by the equipment Hygropalm Model Aw 1. Samples of each moisture content were placed in the recipient of the equipment and subsequently placed in temperature controlled environment, after stabilization of the temperature and water activity, reading was performed. To control the temperature, it was used Biochemical Oxygen Demand (BOD), set at 10, 20, 30 and $40^{\circ} \mathrm{C}$ in three replications.

To the experimental data of water activity were adjusted the mathematical models often used to represent the hygroscopicity of plant products. To determine the thermodynamic properties of pepper seeds of the variety 'Cabacinha', it was used the model of Chung-Pfost (Silva et al., 2015), which adequately represents the experimental data, whose coefficient of determination was $99.66 \%$. Using the model, the water activity values were obtained by means of the following equation:

$X e=30.9217^{* *}-5.0005^{* \star} \cdot \ln \left(-\left(T+127.7755^{* *}\right) \cdot \ln \left(a_{w}\right)\right)(1)$

* Significant at $1 \%$ probability by $t$ test.

wherein, Xe: equilibrium moisture content, \% d.b.; aw: water activity (decimal), and $\mathrm{T}$ : temperature $\left({ }^{\circ} \mathrm{C}\right)$.

The net isosteric heat of sorption (or differential enthalpy) was calculated for each equilibrium moisture content from the Clausius-Clapeyron equation (Equation 2) (Iglesias \& Chirife, 1976). 


$$
\frac{\partial \ln \left(\mathrm{a}_{\mathrm{w}}\right)}{\partial \mathrm{T}}=\frac{\Delta \mathrm{h}_{\mathrm{st}}}{\mathrm{RT}_{\mathrm{a}}^{2}}
$$

wherein, aw: water activity (decimal); $\mathrm{T}_{\mathrm{a}}$ : absolute temperature $(\mathrm{K}) ; \Delta \mathrm{h}_{\mathrm{st}}$ : differential enthalpy $\left(\mathrm{kJ} \mathrm{kg}^{-1}\right)$, and R: universal gas constant $\left(8.314 \mathrm{~kJ} \mathrm{kmol}^{-1} \mathrm{~K}^{-1}\right)$, being, to water vapor, $0.4619 \mathrm{~kJ} \mathrm{~kg}^{-1} \mathrm{~K}^{-1}$.

Integrating Equation 2 and assuming that the net sorption isosteric heat is independent of temperature, the net sorption isosteric heat for each equilibrium moisture content was obtained according to Equation 3 (Wang \& Brennan, 1991; Goneli et al., 2010a):

$\ln \left(\mathrm{a}_{\mathrm{w}}\right)=-\left(\frac{\Delta \mathrm{h}_{\mathrm{st}}}{\mathrm{R}}\right) \cdot \frac{1}{\mathrm{~T}_{\mathrm{a}}}+\mathrm{C}$

wherein, C: coeficiente of the model.

The integral isosteric heat of sorption was obtained by adding the values of the net sorption isosteric heat to the latent heat of vaporization of free water, according to Equation 4 (Al-Muhtaseb et al., 2004; Oliveira et al., 2011):

$\mathrm{Q}_{\mathrm{St}}=\Delta \mathrm{h}_{\mathrm{st}}+\mathrm{L}=\mathrm{a} \cdot \exp (-\mathrm{b} \cdot \mathrm{Xe})+\mathrm{L}$

wherein, Qst: integral isosteric heat of sorption $\left(\mathrm{kJ} \mathrm{kg}^{-1}\right)$; L: latent heat of vaporization of free water $\left(\mathrm{kJ} \mathrm{kg}^{-1}\right)$, and $\mathrm{a}, \mathrm{b}$ : model coefficients.

The latent heat of vaporization of free water (L), in $\mathrm{kJ} \mathrm{kg}^{-1}$, was obtained using the average temperature $(\mathrm{T})$ in the studied range $\left(25^{\circ} \mathrm{C}\right)$, by means of the following equation (Resende et al., 2006; Costa et al., 2013):

$$
L=2502.2-2.39 \cdot T
$$

The differential entropy of desorption $(\Delta S)$, in $\mathrm{kJ} \mathrm{kg}^{-1} \mathrm{~K}^{-1}$, was quantified as the difference between the differential enthalpy of desorption and the change of free energy of Gibbs $(\Delta G)$ of the sorbed water, divided by the absolute temperature $\left(T_{a}\right)$ (Kaya \& Kahyaoglu, 2006; Oliveira et al., 2013):

$$
\Delta \mathrm{S}=\frac{\Delta \mathrm{h}_{\mathrm{st}}-\Delta \mathrm{G}}{\mathrm{T}_{\mathrm{a}}}
$$

wherein, $\Delta S$ : differential entropy of sorption $\left(\mathrm{kJ} \mathrm{kg}^{-1} \mathrm{~K}^{-1}\right)$, and $\Delta \mathrm{G}$ : free energy of Gibbs $\left(\mathrm{kJ} \mathrm{kg}^{-1}\right)$.

To quantify the Gibbs energy $(\Delta G)$, it was used the Equation 7 (Madamba et al., 1996; Telis et al., 2005):

$$
\Delta \mathrm{G}=\mathrm{R} \cdot \mathrm{T} \cdot \ln \left(\mathrm{a}_{\mathrm{W}}\right)
$$

According to Goneli et al. (2010b), the effects of changes in water sorption on free energy are usually accompanied by changes in enthalpy and entropy values. Thus, substituting Equation 7 into Equation 6, there is:

$\ln \left(\mathrm{a}_{\mathrm{W}}\right)=\frac{\Delta \mathrm{h}_{\mathrm{St}}}{\mathrm{RT}}-\frac{\Delta \mathrm{S}}{\mathrm{R}}$

Calculated differential enthalpy $\left(\Delta \mathrm{h}_{\mathrm{st}}\right)$ and entropy $(\Delta S)$ of sorption were correlated by Equation 9 (Beristain et al., 1996):

$$
\Delta \mathrm{h}_{\mathrm{St}}=\mathrm{T}_{\mathrm{B}}(\Delta \mathrm{S})=\Delta \mathrm{G}_{\mathrm{B}}
$$

wherein, $T_{B}$ : isokinetic temperature $(K)$, and $\Delta \mathrm{G}_{\mathrm{B}}$ : Gibbs free energy at isokinetic temperature $\left(\mathrm{kJ} \mathrm{kg}^{-1}\right)$.

To validate the existence of the compensation theory that relates the values of differential enthalpy and entropy of desorption, it was applied the Krung test, which compares the isokinetic temperature with the harmonic mean temperature $(T \mathrm{hm})$, according to the following expression (Krug et al., 1976a; 1976b):

$$
\mathrm{T}_{\mathrm{hm}}=\frac{\mathrm{n}}{\sum\left(\frac{1}{\mathrm{~T}}\right)}
$$

wherein, $T_{h m}$ : harmonic mean temperature $(K)$, and $\mathrm{n}$ : number of temperatures used.

According to Krug et al. (1976a; 1976b), the chemical linear compensation, or compensation theory, exists only if the isokinetic temperature $\left(T_{B}\right)$ is different from the harmonic mean temperature $(T h \mathrm{hm})$. An approximate confidence interval $(1-\alpha ; 100 \%)$, for isokinetic temperature, was calculated by Equation 11:

$$
T_{B}=\hat{T}_{B} \pm t_{m-2, \alpha / 2 \sqrt{\operatorname{Var}(T B)}}
$$

wherein,

$$
\hat{\mathrm{T}}_{\mathrm{B}}=\frac{\sum\left(\Delta \mathrm{h}_{\mathrm{st}}-\overline{\Delta \mathrm{h}_{\mathrm{st}}}\right) \cdot(\Delta \mathrm{S}-\overline{\Delta \mathrm{S}})}{\sum(\Delta \mathrm{S}-\overline{\Delta \mathrm{S}})^{2}}
$$

and

$$
\operatorname{Var}\left(\mathrm{T}_{\mathrm{B}}\right)=\frac{\sum\left(\Delta \mathrm{h}_{\mathrm{st}}-\overline{\Delta \mathrm{G}} \mathrm{B}-\hat{\mathrm{T}}_{\mathrm{B}} \cdot \Delta \mathrm{S}\right)^{2}}{(\mathrm{~m}-2) \sum(\Delta \mathrm{S}-\overline{\Delta \mathrm{S}})^{2}}
$$

where, $\mathrm{m}$ : number of enthalpy and entropy data pairs; $\overline{\Delta \mathrm{h}}_{\mathrm{st}}$ : average enthalpy $\left(\mathrm{kJ} \mathrm{kg}^{-1}\right)$, and $\overline{\Delta S}=$ average entropy $\left(\mathrm{kJ} \mathrm{kg}^{-1}\right)$.

If the harmonic mean temperature $\left(T_{\mathrm{hm}}\right)$ is within the calculated range for isokinetic temperature $\left(T_{B}\right)$, the relation between the values of differential 
enthalpy and entropy of sorption reflects only experimental errors and not the existence of chemical and physical factors that respond to the compensation theory (Beristain et al., 1996). It was adopted, for $T_{B}$, a $99 \%$ confidence interval, across the range of experimental data.

\section{Results and discussions}

The water activity $\left(a_{w}\right)$ values estimated by the Chung-Pfost model (Equation 1) to the equilib- rium moisture content in the range of 3.3 to $23.9 \%$ (d.b.) and temperatures of $10,20,30$ and $40{ }^{\circ} \mathrm{C}$ varied from 0.163 to 0.976 (Table 1). The increase in the equilibrium moisture content and in the temperature caused increases in the water activity values of pepper seeds. This behavior was also observed for corn kernels with a moisture content in the range of 12.8 to $23.3 \%$ (d.b.) and temperatures of $10,20,30$ and $40{ }^{\circ} \mathrm{C}$ (Oliveira et al., 2013).

Table 1 - Water activity values (decimal) estimated by the Chung-Pfost model as a function of the temperature and the hygroscopic equilibrium moisture content of pepper seeds of the variety 'Cabacinha'.

\begin{tabular}{|c|c|c|c|c|c|c|c|c|c|}
\hline \multirow{2}{*}{$\begin{array}{c}\mathrm{Xe} \\
\text { (\% d.b.) }\end{array}$} & \multicolumn{4}{|c|}{ Temperature $\left({ }^{\circ} \mathrm{C}\right)$} & \multirow{2}{*}{$\begin{array}{c}\mathrm{Xe} \\
\text { (\% d.b.) }\end{array}$} & \multicolumn{4}{|c|}{ Temperature $\left({ }^{\circ} \mathrm{C}\right)$} \\
\hline & 10 & 20 & 30 & 40 & & 10 & 20 & 30 & 40 \\
\hline 3.3 & 0.163 & 0.184 & 0.205 & 0.225 & 11.8 & 0.718 & 0.734 & 0.749 & 0.762 \\
\hline 3.5 & 0.172 & 0.194 & 0.215 & 0.236 & 14.4 & 0.819 & 0.831 & 0.840 & 0.849 \\
\hline 3.9 & 0.199 & 0.222 & 0.245 & 0.266 & 14.6 & 0.826 & 0.837 & 0.846 & 0.855 \\
\hline 4.1 & 0.210 & 0.233 & 0.256 & 0.277 & 14.8 & 0.832 & 0.843 & 0.852 & 0.860 \\
\hline 4.2 & 0.220 & 0.244 & 0.267 & 0.289 & 14.9 & 0.837 & 0.847 & 0.856 & 0.864 \\
\hline 5.1 & 0.282 & 0.307 & 0.331 & 0.354 & 15.0 & 0.838 & 0.848 & 0.857 & 0.865 \\
\hline 5.3 & 0.293 & 0.318 & 0.342 & 0.365 & 15.1 & 0.842 & 0.852 & 0.860 & 0.868 \\
\hline 5.4 & 0.305 & 0.330 & 0.354 & 0.377 & 17.1 & 0.890 & 0.898 & 0.904 & 0.909 \\
\hline 5.6 & 0.317 & 0.343 & 0.367 & 0.389 & 17.4 & 0.897 & 0.904 & 0.910 & 0.915 \\
\hline 5.7 & 0.327 & 0.353 & 0.377 & 0.400 & 17.5 & 0.899 & 0.905 & 0.911 & 0.916 \\
\hline 5.8 & 0.329 & 0.354 & 0.378 & 0.401 & 17.6 & 0.901 & 0.908 & 0.913 & 0.918 \\
\hline 5.9 & 0.340 & 0.366 & 0.390 & 0.412 & 17.8 & 0.904 & 0.910 & 0.916 & 0.921 \\
\hline 8.2 & 0.503 & 0.527 & 0.549 & 0.569 & 18.0 & 0.909 & 0.915 & 0.920 & 0.925 \\
\hline 8.3 & 0.511 & 0.535 & 0.556 & 0.576 & 18.4 & 0.915 & 0.920 & 0.925 & 0.929 \\
\hline 8.4 & 0.516 & 0.540 & 0.561 & 0.581 & 21.8 & 0.956 & 0.959 & 0.961 & 0.964 \\
\hline 8.5 & 0.523 & 0.546 & 0.568 & 0.587 & 22.2 & 0.959 & 0.962 & 0.964 & 0.966 \\
\hline 8.6 & 0.533 & 0.556 & 0.577 & 0.597 & 22.6 & 0.962 & 0.965 & 0.967 & 0.969 \\
\hline 8.8 & 0.545 & 0.568 & 0.589 & 0.607 & 22.7 & 0.963 & 0.965 & 0.967 & 0.969 \\
\hline 9.0 & 0.558 & 0.580 & 0.601 & 0.619 & 23.1 & 0.966 & 0.968 & 0.970 & 0.972 \\
\hline 11.1 & 0.681 & 0.699 & 0.715 & 0.729 & 23.2 & 0.966 & 0.969 & 0.971 & 0.972 \\
\hline 11.2 & 0.688 & 0.706 & 0.722 & 0.736 & 23.3 & 0.967 & 0.969 & 0.971 & 0.973 \\
\hline 11.3 & 0.692 & 0.710 & 0.725 & 0.739 & 23.5 & 0.969 & 0.971 & 0.973 & 0.974 \\
\hline 11.4 & 0.697 & 0.714 & 0.729 & 0.743 & 23.9 & 0.971 & 0.973 & 0.974 & 0.976 \\
\hline 11.5 & 0.700 & 0.717 & 0.733 & 0.746 & & & & & \\
\hline
\end{tabular}

The microorganisms, fungi, yeasts and bacteria have minimum threshold value of water activity to perform the metabolic activities of $0.7 ; 0.8$ and 0.9 (decimal), respectively (Oliveira et al., 2005). Thus, to inhibit the growth of these microorganisms during storage, the moisture content of pepper seeds should not exceed values of $11.4 ; 11.1 ; 9.0$ and $9.0 \%$ (d.b.) to temperatures of $10,20,30$ and $40^{\circ} \mathrm{C}$, respectively (Table 1 ).

The integral isosteric heat of desorption (Qst), obtained by adding the net isosteric heat of desorption $\left(h_{s t}\right)$ to the different hygroscopic equilibrium moisture contents and the latent heat of vaporization of free water $\left(\mathrm{L}=2418.55 \mathrm{~kJ} \mathrm{~kg}^{-1}\right)$, increased with the reduction in the equilibrium moisture content of 'Cabacinha' pepper seeds (Figure 1), demonstrating the increased resistance of pepper seeds in evaporating the water attached to their biological structures. This behavior is due basically to the different speeds of migration of the water molecules from the inside to the periphery of the product and of evaporation of the surface water molecules (Corrêa et al., 2010). 


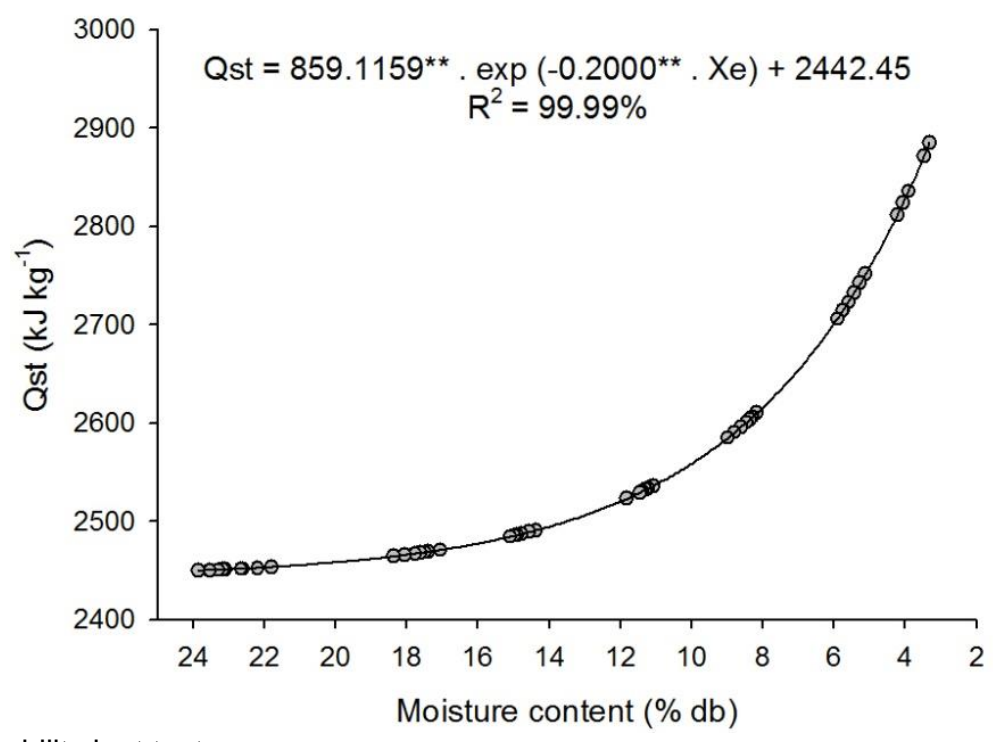

${ }^{* \star}$ Significant at $1 \%$ probability by $t$ test.

Figure 1 - Integral isosteric heat of desorption for pepper seeds of the variety 'Cabacinha'.

The inverse proportionality of Qst compared to Xe (Figure 1) follows the same trend of other agricultural products such as melon seeds (Aviara \& Ajibola, 2002), sesame seeds (Kaya \& Kahyaoglu, 2006), beans (Resende et al., 2006), okra seeds (Goneli et al., 2010a), millet grains (Goneli et al., 2010b), corn grains (Oliveira et al., 2010; Oliveira et al., 2013) and crambe fruits (Costa et al., 2013).

The values of integral isosteric heat of desorption for pepper seeds in the moisture content range of 23.9 to $3.3 \%$ (d.b.) varied from 2449.7 to $2885.4 \mathrm{~kJ} \mathrm{~kg}^{-1}$ (Figure 1). In corn grains with moisture content in the range from 23.3 to $12.8 \%$ (d.b.), the integral isosteric heat of desorption varied from 2506 to $2734 \mathrm{~kJ} \mathrm{~kg}^{-1}$ (Oliveira et al., 2013). On the other hand, the integral isosteric heat of desorption for millet grains with moisture content ranging from 35.2 to $11.0 \%$ (d.b.) was between 2457 and $3550 \mathrm{~kJ} \mathrm{~kg}^{-1}$ (Goneli et al., 2010b).

Possible diferences found between the values of integral isosteric heat of desorption for different products can be justified by the inherent factors of each product (Resende et al., 2006), with the differences in the composition and structure of products being assigned to the data of equilibrium moisture content and the method of its determination (Aviara \& Ajibola, 2002) and to the mistakes in obtaining the water activity values, since these values are determined from the mathematical models (Ferreira \& Pena, 2003).

The enthalpy and entropy presented, respectively, values of 7.279 to $442.933 \mathrm{~kJ} \mathrm{~kg}^{-1} \mathrm{~K}^{-1}$ and 0.012 to $0.728 \mathrm{~kJ} \mathrm{~kg}^{-1} \mathrm{~K}^{-1}$ for the equilibrium moisture content in the range of 23.9 to $3.3 \%$ (d.b.) (Figure 2). The values of these two variables increase with the reduction of the moisture content of the seeds, agreeing with the results for various agricultural products (Madamba et al., 1996; Aviara \& Ajibola, 2002; Al-Muhtaseb et al., 2004; Kaya \& Kahyaoglu, 2006; Goneli et al., 2010a; Goneli et al., 2010b; Oliveira et al., 2011; Goneli et al., 2013).

The regression equations fitted to the experimental data of enthalpy and entropy of pepper seeds have high coefficients of determination $\left(R^{2}=99.99 \%\right)$ and significant parameters to $1 \%$ significance by $t$ test, showing the adequacy of the equations to the experimental data (Table 2).

The relationship between the differential enthalpy and entropy involved in the desorption process showed a linear behavior with a high coefficient of determination $\left(R^{2}=99.99 \%\right)$, validating the isokinetic theory, or theory of enthalpy-entropy compensation (Figure 3).

To test the validity of the theory of the enthalpy-entropy compensation, the isokinetic temperature was compared with the harmonic mean $\left(T_{\mathrm{hm}}\right)$ of the temperature range used to determine the desorption process in pepper seeds. According to Krug et al. (1976a; 1976b), the chemical linear compensation only exists if the isokinetic temperature $T_{B}$ is different from the harmonic mean temperature $\mathrm{Thm}$. Thus, as obtained in the present work, the isokinetic temperature of pepper seeds $(608.4334 \pm 0.00010)$ is significantly different from the calculated harmonic mean $(292.35 \mathrm{~K})$, confirming the enthalpy-entropy compensation phenomenon. 


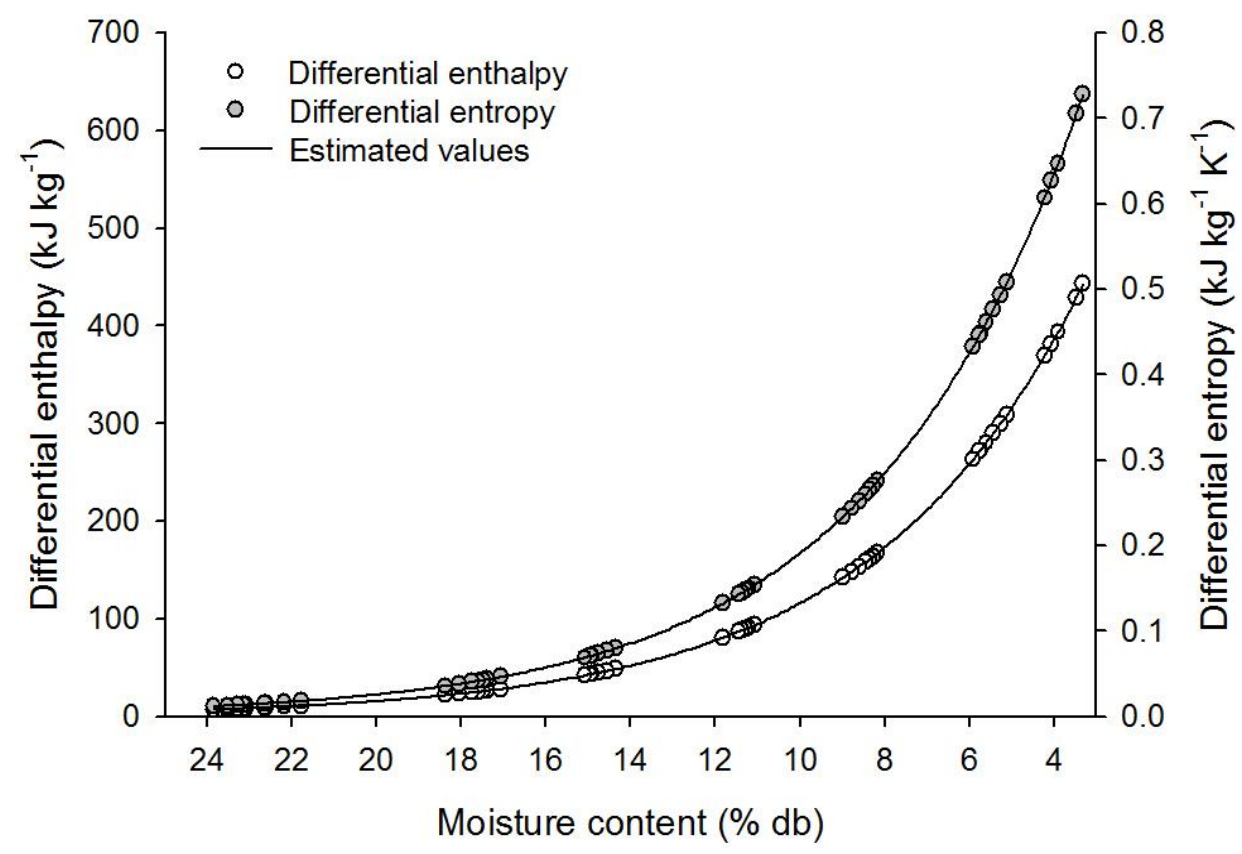

Figure 2 - Experimental and estimated values of differential enthalpy and entropy of desorption of the pepper seeds from the variety 'Cabacinha'.

Table 2 - Equations and determination coefficients of differential enthalpy ( $\Delta$ hst) and entropy $(\Delta S)$ of desorption of pepper seeds from the variety 'Cabacinha'.

\begin{tabular}{lcc}
\hline Thermodynamic Properties & Equations & $\mathrm{R}^{2}(\%)$ \\
\hline Differential Enthalpy & $\Delta \mathrm{h}_{\mathrm{st}}=0.0002^{* *}+859.1159^{* *} . \exp \left(-0.2000^{* *} \cdot \mathrm{Xe}\right)$ & 99.99 \\
Differential Entropy & $\Delta S=5.3501 \times 10^{-6^{* *}}+1.412^{* *} \cdot \exp \left(-0.2000^{* *} \cdot \mathrm{Xe}\right)$ & 99.99 \\
\hline
\end{tabular}

${ }^{\star *}$ Significant at $1 \%$ probability by $t$ test.

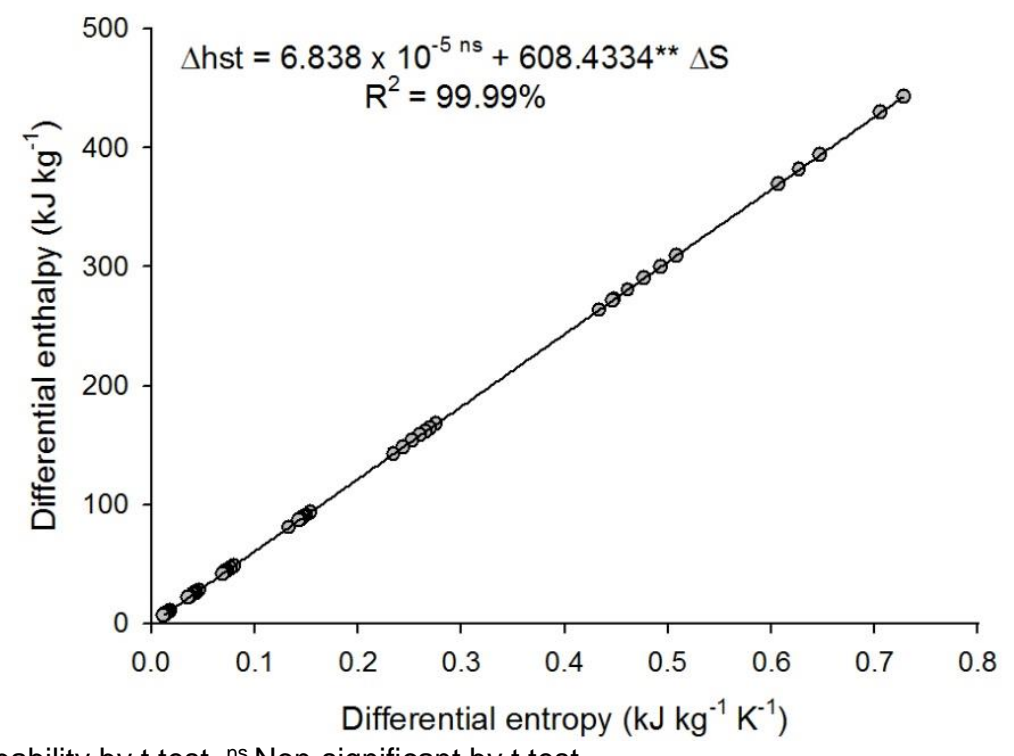

${ }^{*}$ Significant at $1 \%$ probability by $t$ test. ${ }^{\text {ns }}$ Non-significant by $t$ test.

Figure 3 - Enthalpy-entropy relationship for the process of desorption of water from pepper seeds of the variety 'Cabacinha'. 
In the linear enthalpy-entropy compensation, the process is controlled by enthalpy when $T_{B}>T_{h m}$, otherwise $\left(T_{B}<T_{h m}\right)$, the process is controlled by entropy (Telis-Romero et al., 2005). From this criterion and the results obtained in this work, the isokinetic temperature was higher than the harmonic mean temperature, the process being controlled by enthalpy. These results corroborate those reported by several researchers (Telis et al., 2000; McMinn et al., 2005; Goneli et al., 2010b; Thys et al., 2010; Goneli et al., 2013; Oliveira et al., 2013), in studies of various agricultural products.
The Gibbs free energy presented positive values (Figure 4), showing that the desorption of water in pepper seeds is not a spontaneous process (Telis et al., 2000). The values of Gibbs free energy in the four temperatures increased by reducing the moisture content of pepper seeds, tending to stabilize at higher levels of moisture content, for seeds present a greater number of sorption active sites (Goneli et al., 2013). Similar behaviors were observed for coffee beans (Corrêa et al., 2010), okra seeds (Goneli et al., 2010a) and corn kernels (Oliveira et al., 2013).

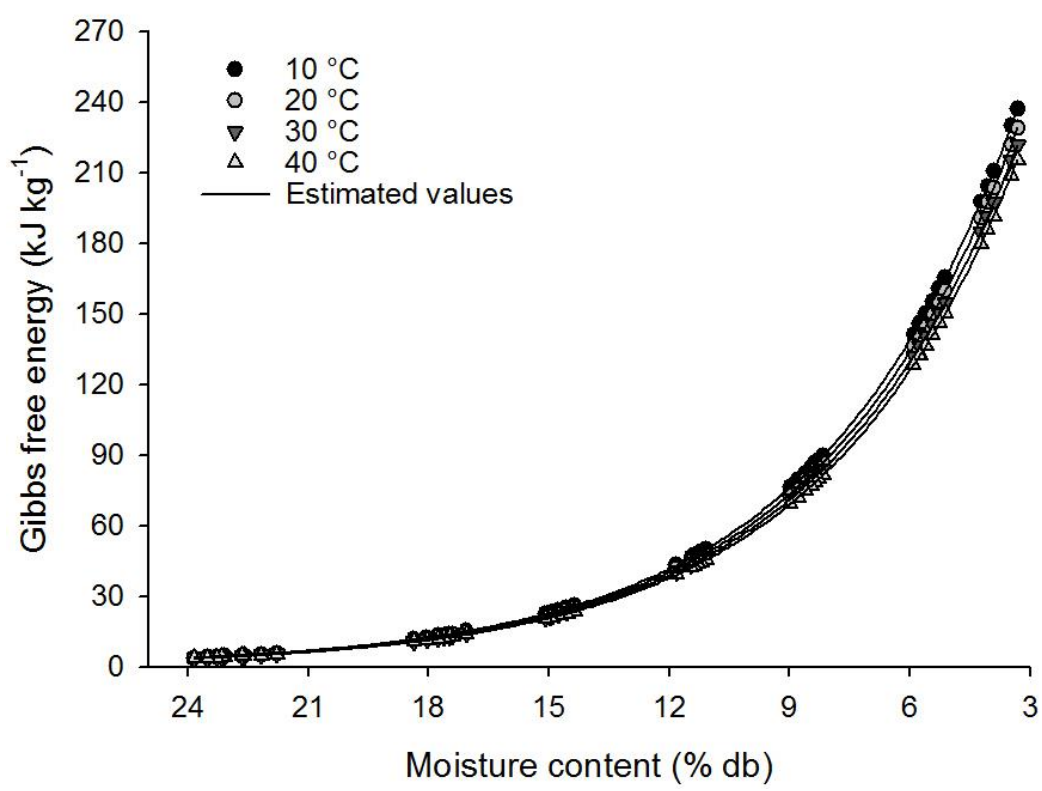

Figure 4 - Gibbs free energy as a function of the moisture content of pepper seeds of the variety 'Cabacinha'.

The influence of temperature on the Gibbs free energy is higher for lower moisture contents, and the increase in temperature reduces the Gibbs energy (Figure 4). According to Goneli et al. (2013), this trend can be correlated to the vibration or movement of water molecules in the interior of the product, presenting at high temperatures a greater vibration; this leads to a lower need for labor for the layers of the product to be available for sorption.

Nkolo Meze'e et al. (2008) report that the Gibbs free energy is attributed to the work needed to make the sorption sites available. The positive Gibbs free energy values are characteristic of an exogenous reaction, ie, one that requires an external agent supplying energy to the environment.

The equations fitted to the data of the Gibbs free energy showed high coefficients of determination $\left(R^{2}=99.99 \%\right)$ and significant parameters to $1 \%$ significance by t test (Table 3), demonstrating the satisfactory adjustment of the equations to the experimental data.

Table 3 - Equations and determination coefficients of Gibbs free energy of pepper seeds of the variety 'Cabacinha'.

\begin{tabular}{lcl}
\hline Temperature $\left({ }^{\circ} \mathrm{C}\right)$ & Equations & $\mathrm{R}^{2}(\%)$ \\
\hline 10 & $\Delta \mathrm{G}=460.1926^{* *} \exp \left(-0.2000^{* *} \mathrm{Xe}\right)$ & 99.99 \\
20 & $\Delta \mathrm{G}=444.2040^{* *} \exp \left(-0.2000^{* *} \mathrm{Xe}\right)$ & 99.99 \\
30 & $\Delta \mathrm{G}=430.2422^{* *} \exp \left(-0.2000^{* *} \mathrm{Xe}\right)$ & 99.99 \\
40 & $\Delta \mathrm{G}=417.9448^{* *} \exp \left(-0.2000^{* *} \mathrm{Xe}\right)$ & 99.99 \\
\hline
\end{tabular}

${ }^{\star \star}$ Significant at $1 \%$ probability by t test. 


\section{Conclusions}

The integral isosteric heat of desorption, the differential entropy and enthalpy and the Gibbs energy increased by reducing the moisture content of pepper seeds of the variety 'Cabacinha', reflecting a higher energy requirement for water removal of the product.

The enthalpy-entropy compensation is valid for the desorption of water in the seeds, this process being controlled by enthalpy.

Gibbs energy showed positive values for the temperatures studied, showing that the process is not spontaneous.

\section{Acknowledgements}

To IF Goiano, CAPES, FINEP and CNPq for the essential financial support for implementing this work.

\section{References}

Al-Muhtaseb AH, McMinn WAM, Magee TRA (2004). Water sorption isotherms of starch powders. Part 2: Thermodynamic characteristic. Journal of Food Enginerring 62(2):135-142.

Araújo LF Corrêa PC, Silva RF (2001) Comparação de modelos matemáticos para descrição das curvas de dessorção de sementes de milho-doce. Pesquisa Agropecuária Brasileira 36(7):991-995.

Aviara NA, Ajibola OO (2002) Thermodynamics of moisture sorption in melon seed and cassava. Journal of Food Engineering 55(2):107-113.

Beristain Cl, Garcia HS, Azuara E (1996) Enthalpyentropy compensation in food vapor adsorption. Journal of Food Engineering 30(3-4):405-415.

Brasil, Ministério da Agricultura e Reforma Agrária (2009) Secretaria Nacional de Defesa Agropecuária. Regras para análise de sementes. Brasília: Mapa/ACS. 399p.

Corrêa PC, Oliveira GHH, Botelho FM, Goneli ALD, Carvalho FM (2010) Modelagem matemática e determinação das propriedades termodinâmicas do café (Coffea arabica L.) durante o processo de secagem. Revista Ceres 57(5):595-601.

Costa LM, Resende O, Oliveira DEC (2013) Isotermas de dessorção e calor isostérico dos frutos de crambe. Revista Brasileira de Engenharia Agrícola e Ambiental 17(4):412-418.

Fasina $O O$ (2006) Thermodynamic properties of sweet potato. Journal of Food Engineering 75(2):149-155.

Ferreira CD, Pena RS (2003) Comportamento higroscópico da farinha de pupunha (Bactris gasipaes). Ciência e Tecnologia de Alimentos 23(2):251-255.

Goneli ALD, Corrêa PC, Oliveira GHH, Afonso Júnior PC (2013) Water sorption properties of coffee fruits, pulped and green coffee. Food Science and Technology 50(2):386-391.
Goneli ALD, Corrêa PC, Oliveira GHH, Botelho FM (2010a) Water desorption and thermodynamic properties of okra seeds. Transaction of the ASAE 53(1):191-197.

Goneli ALD, Corrêa PC, Oliveira GHH, Gomes CF, Botelho FM (2010b) Water sorption isotherms and thermodynamic properties of pearl millet grain. International Journal of Food Science and Technology 45(2):282-383.

Iglesias H, Chirife J (1976) Prediction of the effect of temperature on water sorption isotherms of food material. Journal of Food Technology 11(2):109-116.

Kaya S, Kahyaoglu T (2006) Influence of dehulling and roasting process on the thermodynamics of moisture adsorption in sesame seed. Journal of Food Engineering 76(2):139-147.

Krug RR, Hunter WG, Grieger RA (1976a) Enthalpyentropy compensation: 1 - some fundamental statistical problems associated with the analysis of Van't Hoff and Arrhenius data. Journal of Physical Chemistry 80(21):2335-2341.

Krug RR, Hunter WG, Grieger RA (1976b) Enthalpyentropy compensation: 2 - separation of the chemical from the statistical effect. Journal of Physical Chemistry 80(21):2341-2351.

Madamba PS, Driscoll RH, Buchkle KA (1996) Enthalpy-entropy compensation models for sorption and browning of garlic. Journal of Food Engineering 28(2):109-119.

McMinn WAM, Al-Muhtaseb AH, Magee TRA (2005) Enthalpy-entropy compensation in sorption phenomena of starch materials. Food Research International 38(5):505-510.

Moreira R, Chenlo F, Torres MD, Vallejo N (2008) Thermodynamic analysis of experimental sorption isotherms of loquat and quince fruits. Journal of Food Engineering 88(4):514-521.

Nkolo Meze'e YN, Ngamveng JN, Bardet S (2008) Effect of enthalpy-entropy compensation during sorption of water vapour in tropical woods: the case of Bubinga (Guibourtia Tessmanii J. L'eonard; G. Pellegriniana J. L.). Thermochimica Acta 468(3-4):1-5.

Oliveira DEC, Resende O, Smaniotto TAS, Sousa KA, Campos RC (2013) Propriedades termodinâmicas de grãos de milho para diferentes teores de água de equilíbrio. Pesquisa Agropecuária Tropical 43(1):50-56.

Oliveira GHH, Corrêa PC, Araújo EF, Valente DSM, Botelho FM (2010) Desorption isotherms and thermodynamic properties of sweet corn cultivars (Zea mays L.). International Journal of Food Science and Technology 45(3):546-554. 
Oliveira GHH, Corrêa PC, Santos ES, Treto PC, Diniz MDMS (2011) Evaluation of thermodynamic properties using GAB model to describe the desorption process of cocoa beans. International Journal of Food Science and Technology 46(10):2077-2084.

Oliveira MM, Campos ARN, Gomes JP, Silva FLH (2005) Isotermas de sorção do resíduo agroindustrial de casca do abacaxi (Ananas comosus L. Mer). Revista Brasileira de Engenharia Agrícola e Ambiental 9(4):565-569.

Resende O, Corrêa PC, Goneli ALD, Ribeiro DM (2006) Isotermas e calor isostérico de sorção do feijão. Ciência e Tecnologia dos Alimentos 26(3):626-631.

Silva HW, Costa LM, Resende O, Oliveira DEC, Soares RS, Vale LSR (2015) Higroscopicidade das sementes de pimenta (Capsicum chinense L.). Revista Brasileira de Engenharia Agrícola e Ambiental 19(8):780-784.
Telis VRN, Gabas FC, Menegalli J, Telis-Romero J (2000) Water sorption thermodynamic properties applied to persimmon skin and pulp. Thermochimica Acta 343(1-2):49-56.

Telis-Romero J, Kohayakawa MN, Silveira Júnior V, Pedro MAM, Gabas AL (2005) Enthalpy-entropy compensation based on isotherms of mango. Ciência e Tecnologia de Alimentos 25(2):297-303.

Thys RCS, Noreña CPZ, Marczak LDF, Aires AG, Cladera-Olivera F (2010) Adsorption isotherms of pinhão (Araucaria angustifolia seeds) starch and thermodynamic analysis. Journal of Food Engineering 100(3):468-473.

Wang N, Brennan JG (1991) Moisture sorption isotherm characteristics of potato at four temperatures. Journal of Food Engineering 14(1):269-287. 